\title{
Feeding ecology of Serrasalmus gouldingi (Characiformes: Serrasalmidae) in the lower Anapu River region, Eastern Amazon, Brazil
}

\author{
Bruno da S. PRUDENTE ${ }^{1 *}$, Pedro CARNEIRO-MARINHO ${ }^{1}$, Roberta de M. VALENTE², Luciano F. de A. \\ MONTAG $^{1}$ \\ 1 Universidade Federal do Pará, Laboratório de Ecologia e Conservação, Instituto de Ciências Biológicas, Rua Augusto Corrêa 01- Guamá, CEP 66075-110, Belém, Pará - Brazil . \\ 2 Universidade Federal do Pará, Laboratório de Invertebrados, Instituto de Ciências Biológicas, Rua Augusto Corrêa, 01- Guamá, CEP 66075-110, Belém, Para - Brazil. \\ *Corresponding author: brunoprudente8@gmail.com
}

\begin{abstract}
Studies on feeding ecology of fishes are important to understand the relationship between species and environmental seasonal variations. In tropical rivers, these relationships are mainly modeled by hydrological patterns. Thereby, this study aimed to assess the influence of fluviometric variation and life stage (juveniles and adults) in the feeding ecology of Serrasalmus gouldingi in the lower Anapu River region, located in Eastern Amazon, Pará, Brazil. Specimens were collected bimonthly, considering four different hydrological periods. We assessed the diet composition, feeding intensity and niche breadth of the species. Thirty-two dietary items were identified and grouped into ten categories. A total of 279 stomachs were analyzed, showing a predominance of fish fragments, followed by fruits and seeds. The diet composition of $S$. gouldingi differed only between drought and flood season, although it did not differ between juveniles and adults. An increase in feeding intensity was recorded during the rise in the water level, with a lower feeding intensity observed during transitional season. Serrasalmus gouldingi showed lower niche breadth during flood season, attributed to the high consumption of fruits and seeds, presenting an omnivorous diet with high tendency towards piscivory. Although less evident than in other Amazon watersheds, the flood pulse in the lower Anapu River region is an important factor influencing the feeding ecology of the species.
\end{abstract}

KEYWORDS: Amazon basin, diet, flood pulse, niche breadth, repletion index.

\section{Ecologia alimentar de Serrasalmus gouldingi (Characiformes: Serrasalmidae) na região do baixo Rio Anapu, Amazônia Oriental, Brasil}

\section{RESUMO}

Estudos sobre ecologia trófica dos peixes são importantes ferramentas para compreensão das relações entre as espécies e as variaçôes sazonais no ambiente. Em rios tropicais essas relaçôes são modeladas principalmente por variaçôes hidrológicas. Sendo assim, o objetivo presente estudo é avaliar a influência variação fluviométrica e do estágio de vida (juvenis e adultos) na ecologia alimentar de Serrasalmus gouldingi na regiáo do baixo Rio Anapu, Amazônia Oriental, Pará, Brasil. Os espécimes foram amostrados bimensalmente considerando quatro períodos hidrológicos distintos. Nós avaliamos a composição da dieta, intensidade alimentar e amplitude de nicho da espécie. Foram identificados trinta e dois itens alimentares agrupados em dez categorias. Um total de 279 estômagos foi analisado, registrando um predomínio no consumo de fragmento de peixes seguido por frutos e sementes. A composição na dieta de $S$. gouldingi diferiu apenas entre os períodos de seca e cheia, não diferindo entre juvenis e adultos. Uma maior intensidade alimentar foi observada durante o aumento do nível dos rios, com uma menor intensidade alimentar durante os períodos transicionais. Durante o período de cheia $S$. gouldingi também evidenciou uma menor amplitude de nicho, a qual foi atribuída ao elevado consumo de frutos e sementes. Sendo assim, a dieta de $S$. gouldingi foi classificada como onívora com forte tendência a piscivoria. Embora menos evidente do que em outras regióes da Amazônia, o pulso de inundação na regiáo do baixo Rio Anapu também afeta a ecologia alimentar da espécie.

PALAVRAS-CHAVE: Bacia Amazônica, dieta, pulso de inundação, amplitude de nicho, índice de repleção. 


\section{INTRODUCTION}

Studies on the feeding ecology of fishes have been an important tool to understand ecological patterns such as habitat preference and fish-habitat interactions, which are frequently related to environmental variations and with resource availability and accessibility (Braga et al. 2012; Correa and Winemiller 2014). In tropical rivers, flood pulse has a major influence on feeding ecology of fishes, resulting in changes in foraging areas and food availability (Junk et al. 1989; Luz-Agostinho et al. 2008; Mortillaro et al. 2015).

Changes in the diet of fishes may result either from variations in food availability or from ontogenetic variations. In different life stages, some reproductive aspects cause physiological limitation, once adult individuals require powerful energetic resources for sexual maturation (Scarnecchia et al. 2007; Ballesteros et al. 2009). Morphological differences in adults and juveniles may also affect diet, due to development degree of dentition and swimming ability of individuals.

Studies on trophic ecology of Serrasalmus revealed that despite its morphological adaptations to a piscivorous diet (Machado-Allison and Garcia 1986), plant fragments, fruits and seeds have been found in different proportions (Trindade and Juca-Chagas 2008; Horn et al. 2011; Ferreira et al. 2014). According to literature, the consumption of fruits or seeds may occur accidentally, or in response to their availability for a specific period, or even as a strategy to maximize energetic gain during flood seasons (Behr and Signor 2008; Correa and Winemiller 2014). However, little information is available on the feeding behavior of Serrasalmus, hampering any conclusive understanding of processes that lead to the ingestion of these items as well as their importance in the diet of this species (Sazima and Machado 1990).

In the Amazon basin, the high spatial dimension and structural complexity result in regions with different geomorphology, river flow intensity and precipitation rates, causing different intensities of flood pulse (Junk and Furch 1993). In this sense, hydrographic peculiarities of the region of lower Anapu River stand out due to the natural damming of its rivers and streams, influenced both by tides and by the outflow of Anapu River, resulting in a reduced annual flood pulse (Behling and Costa 2000). In this region, Serrasalmus gouldingi is among the most abundant fish species, representing $67 \%$ of subsistence fishing, along with other species of piranhas (Montag et al. 2009a). This species occurs throughout the Amazonas and Orinoco River basins and is a typical black water and lentic environments dweller (Fink and Machado-Allison 1992). Considering the reduced flood pulse of the region, we expect that variation in diet composition of $S$. gouldingi would be lower between distinct hydrological periods than between different life stages, with juveniles and adults showing a different variation pattern in feeding intensity and niche breadth. Therefore, this study aimed to assess the influence of fluviometric variation and life stage (juveniles and adults) in the feeding ecology of S. gouldingi in the lower Anapu River region, located in Eastern Amazon, Pará, Brazil.

\section{MATERIALS AND METHODS}

\section{Study area}

This study was conducted in the rivers of the region of the lower Anapu River in Caxiuanã National Forest ( $1^{\circ} 45^{\prime} 27.5^{\prime \prime} \mathrm{S}$, $\left.51^{\circ} 27^{\prime} 33.2^{\prime \prime} \mathrm{W}\right)$, located in the Xingu-Tocantins interfluvium, Pará state, eastern Brazilian Amazon (Figure 1). The climate is tropical subtype "Am", hot and humid, according to Köppen classification, with a short drought season between August and November and annual mean precipitation of 2,020 mm (Moraes et al. 2009).

Located in the Amazon lowland plain, the study area is characterized as a "ria lake", formed by the flooding of the river valley due to aggradation processes that occurred during the Holocene (Hida et al. 1999). This geological event resulted in the natural damming of the basin and the loss of its floodplains, forming a typical "drowned river" landscape, with a constant relationship between marginal forest and aquatic ecosystem (Behling and Costa 2000).

Rivers in this region are typical black water habitats, characterized by relatively subtle fluviometric fluctuations, which rarely exceed $1 \mathrm{~m}$ (Hida et al. 1999). These rivers are influenced by tides and the discharge of the Anapu River, which combined result in a greatly reduced annual flood pulse (Behling and Costa 2000). Nonetheless, it is possible to observe four distinct hydrological periods - receding water (June-August), drought (September-November), rising water (December-February), and flood (March-May). These hydrologic periods were previously defined by Freitas et al. (2011) that investigated the effect of fluviometric variation in the feeding ecology of catfish Auchenipterichthys longimanus in the same region of the present study.

\section{Data collection and analysis}

Specimens of Serrasalmus gouldingi Fink and MachadoAllison 1992 (Serrasalmidae) were collected bimonthly from July, 2010 to May, 2011. Each field expedition consisted of five-day samplings using two sets of gillnets, $100 \mathrm{~m}$ long and approximately $1.5 \mathrm{~m}$ in height, with mesh ranging from 3 to $12 \mathrm{~cm}$ between opposite knots. Gillnets were set along the study area forming 45 degrees with the river bank in places with depth range up to $3 \mathrm{~m}$, always between 04:00 am and 08:00 am and between 4:00 pm and 8:00 pm, totalizing 180 sampling points.

Immediately after capture, the fishes were fixed in $10 \%$ formalin solution until dissection. Sampling of specimens 


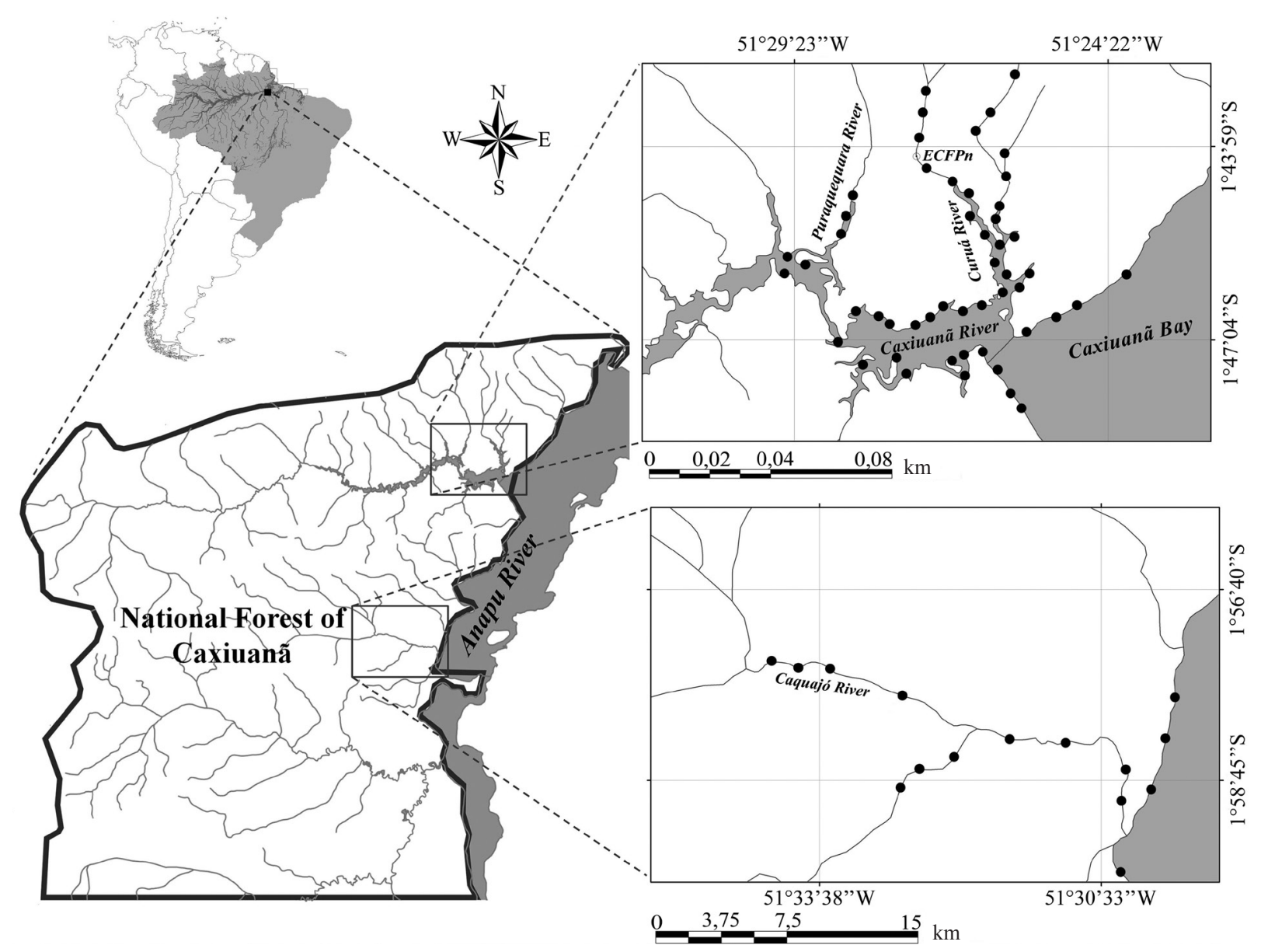

Figure 1. Region of the lower Anapu River, showing the Caxiuanã National Forest and the collecting localities (black circle) in the principal study rivers - Caxiuanã, Curuá, Puraquequara, and Caquajó. A single point on the map may represent more than one collecting site.

was conducted using license number $25060-1$ granted by the Biodiversity Authorization and Information System -SISBIO. The fluviometric variation was obtained from fluviometric stations of the National Agency of Water (ANA) located in the low Anapu River region.

At the laboratory, specimens were weighted (total mass in grams $-\mathrm{M}_{\mathrm{T}}$ ), measured (total length in centimeters $-\mathrm{L}_{\mathrm{T}}$ ) and gutted, for the removal of stomach. Stomachs were fixed in $4 \%$ formalin solution for 24 hours, and then stored in $70 \%$ ethanol for subsequent content analysis. Information about the life stages of specimens was obtained based on mean size at first maturity, which was $12.24 \mathrm{~cm}$ for males and 16.13 $\mathrm{cm}$ for females, according to Prudente et al. (2015). Adults specimens were defined as having a total length greater than values mentioned above, while juveniles specimens would have an inferior total length.

Voucher specimens were fixed in $10 \%$ formalin solution for 48 hours, stored in $70 \%$ alcohol, and deposited in the ichthyological collection of Museu Paraense Emílio Goeldi (MPEG, Belém, Brazil) under catalog numbers MPEG1893518940, MPEG18942-18943, MPEG18949, MPEG1918619189, MPEG19199, MPEG19299, MPEG19301-19306, MPEG19310-19315, MPEG22923-22933, MPEG2293922968.

Stomach contents were analyzed under stereomicroscope (Stemi DV4 - 32x, Zeiss, Jena, Germany) and dietary items were identified to the lowest taxonomic level possible (Costa et al. 2006). Dietary items were weighed on a balance with $0.00001 \mathrm{~g}$ precision (AUW 220D, Shimadzu, Philippines) and the frequency of occurrence, $\mathrm{FO}_{\mathrm{i}} \%$ (Hyslop 1980) and relative mass, $M_{i} \%$ (Hynes 1950) were determined. These measures were combined to obtain the Alimentary Index (Kawakami and Vazzoler 1980), which is given by:

$$
A I i=(F O i \% * M i \% / \Sigma F O i \% * M i \%) * 100, \text { where }
$$
$\mathrm{AI}_{\mathrm{i}} \%=$ importance index of item $\mathrm{i}, \mathrm{FO}_{\mathrm{i}} \%=$ frequency of occurrence of item $i$, and $M_{i} \%$ = total mass of item $i$. 
To assess the diet variation in S. gouldingi in relation to the hydrological periods and between juveniles and adults, dietary items were grouped in 10 categories: allochthonous arthropods, mammal fragments, autochthonous insects, crustaceans, fish fragments, fragments of fruits and seeds, other plant fragments (non-reproductive parts), algae, arthropod fragments (unknown origin) and inorganic material (unknown origin). The values of alimentary index for each dietary category were log-transformed to obtain a similarity matrix (Bray-Curtis) and submitted to a nonmetric multidimensional scaling analysis (nMDS). This analysis assessed the distortion or stress between the similarity matrix and the clustering pattern revealed in the graphic representation, providing a reliability measure of the analysis for results interpretation (Clarke and Warwick 2001).

A Permutational Multivariate Analysis of Variance (PERMANOVA - Anderson 2001) was performed to test the null hypothesis that diet composition does not differ between hydrological periods and between juveniles and adults. This analysis was followed by a similarity percentage analysis (SIMPER) used to determine which diet category was most responsible for diet similarity within each hydrological periods and life stage (juveniles and adults). These analyses were performed using PRIMERv6.1.11 ${ }^{\circ}$ (Clarke and Gorley 2006) with PERMANOVA+1.0.3. add - on package (Anderson et al. 2008). The significance of multivariate dispersion generated by PERMANOVA was assessed using a Monte Carlo test with 10,000 permutations, followed by a post hoc pair wise comparison between hydrological seasons.

Feeding intensity was assessed through the Repletion Index (RI\%), based on the equation:

$R I \%=\left(M_{S} / M_{T}\right) * 100$, where $\mathrm{M}_{\mathrm{S}}=$ total stomach mass (sum of the weight of different items), and $\mathrm{M}_{\mathrm{T}}=$ total specimen mass (Zavala-Camin 1996).

To test the RI\% variation among hydrological periods and in juveniles and adults, a Kruskal-Wallis test was used, complemented by a posteriori test (Zar 1999) using the software Statistica 8.0 (Statsoft Inc., 2007). A significance level of 0.05 was considered, excluding outliers.

Finally, the relative level of specialization of $S$. gouldingi diet was estimated using the standardized Levins' index, adapted by Hurlbert (1978), given by:

$B a=\left[\left(\Sigma j P^{2} i j\right)\right]^{-1}(n-1)^{-1}$, where $\mathrm{Ba}=$ niche breadth, $\mathrm{Pij}=$ proportion of item $\mathrm{j}$ in the diet of species $\mathrm{i}$, and $\mathrm{n}=$ total number of items.

This index ranges from zero (when the species consumes only one type of item) to one (when the species consumes all items in equal proportions) and was calculated using the software Microsoft Office Excel $^{\circledR}$ 2010. This variation was qualitatively assessed in relation to the seasonal fluctuations in water levels.

\section{RESULTS}

A total of 279 stomachs were analyzed; 170 from adults and 109 from juveniles. Regarding hydrological periods, 52 stomachs were sampled during receding water season $(26$ juveniles and 26 adults), 80 during drought season $(25,55), 64$ during rising water season $(30,34)$ and 83 during flood season $(28,55)$. Species diet was composed of 32 items, of which $53.12 \%$ derived from autochthonous sources, $37.50 \%$ from allochthonous sources and $9.38 \%$ were of unknown origin. Considering the entire set of dietary categories, the $\operatorname{diet}$ of $S$. gouldingi was composed primarily by fish fragments $\left(\mathrm{AI}_{\mathrm{i}} \%\right.$ $=63.71 \%)$, followed by fruits and seeds $\left(\mathrm{AI}_{\mathrm{i}} \%=29.14 \%\right)$ and by allochthonous arthropods $\left(\mathrm{AI}_{\mathrm{i}} \%=3.66 \%\right)$, with all other items (fragments of mammals, autochthonous insects, crustaceans, non-reproductive plant parts, algae, fragments of arthropods [unknown origin] and inorganic material [unknown origin]) returning AIi\% values lower than 2\% (Table 1).

Despite the fragmentation and digestion degree of fish fragments, the predominance of fishes from the order Characiformes was confirmed, followed by Siluriformes, Synbranchiformes and Gymnotiformes. Fruits and seeds were the second most important item overall $\left(\mathrm{AI}_{\mathrm{i}} \%=\right.$ $29.14 \%$ ), and the most important item during flood season $\left(\mathrm{AI}_{\mathrm{i}} \%=81.05 \%\right.$ in March). In the case of allochthonous arthropods, there was a predominance of Isoptera $\left(\mathrm{AI}_{\mathrm{i}} \%=\right.$ $0.78 \%$ ), which was more important during flood season, followed by insect fragments $\left(\mathrm{AI}_{\mathrm{i}} \%=0.42 \%\right)$ (Table 1$)$.

The nMDS analysis indicated a distinct diet during flood season in relation to other hydrological periods (Figure 2A), with no evident distinction between juveniles and adults. The PERMANOVA results showed that diet composition was not different between juveniles and adults $\left({ }_{\text {pseudo }} \mathrm{F}=0.92, \mathrm{p}=0.44\right)$; however, they indicated that $S$. gouldingi had significantly different diets between hydrological periods $\left({ }_{\text {pseudo }} \mathrm{F}=2.54, \mathrm{p}=0.02\right)$. Pairwise tests found a significantly difference in diet between drought and flood season ( $t=1.98, \mathrm{p}=0.03)$, with no difference between the following seasons: receding water and drought season $(t=1.56, p=0.11)$; receding water and rising water season $(\mathrm{t}=1.80, \mathrm{p}=0.16)$; receding water and flood season $(\mathrm{t}=$ $1,53, \mathrm{p}=0.14)$; rising water and drought season $(\mathrm{t}=1, \mathrm{p}=$ $0.41)$ and rising water and flood season $(\mathrm{t}=1.32, \mathrm{p}=0.23)$.

According to SIMPER analysis, the average diet similarity was $74.13 \%$ during drought season, where fish fragment contributed with $64.33 \%$ of the species diet, followed by fragments of fruits and seeds (11.97\%) and arthropod fragments $(10.40 \%)$. During the flood season 
Table 1. Alimentary Index $\left(A I_{i}\right)$ for the different categories and items in the diet of Serrasalmus gouldingi in the lower Anapu River region between July, 2010, and May, 2011. The food items highlighted in bold represent the established feeding categories. Juveniles specimens (Juv), Adults specimens (Adu).

\begin{tabular}{|c|c|c|c|c|c|c|c|c|c|c|c|c|c|c|c|c|c|c|c|}
\hline \multirow{3}{*}{ Food items } & \multicolumn{6}{|c|}{ Receding water } & \multirow{2}{*}{\multicolumn{3}{|c|}{$\begin{array}{c}\text { Drought } \\
\text { Nov./2010 }\end{array}$}} & \multirow{2}{*}{\multicolumn{3}{|c|}{$\begin{array}{c}\text { Rising water } \\
\text { Jan./2011 }\end{array}$}} & \multicolumn{6}{|c|}{ Flood } & \multirow{3}{*}{$\begin{array}{l}\text { IAi\% } \\
\text { Tota }\end{array}$} \\
\hline & \multicolumn{3}{|c|}{ Jul./2010 } & \multicolumn{3}{|c|}{ Sep./2010 } & & & & & & & & Mar./20 & & & /ay/20 & & \\
\hline & Juv & Adu & Total & Juv & Adu & Total & Juv & Adu & Total & Juv & Adu & Total & Juv & Adu & Total & Juv & Adu & Total & \\
\hline \multicolumn{20}{|l|}{$\begin{array}{l}\text { Animal } \\
\text { (allochthonous) }\end{array}$} \\
\hline $\begin{array}{l}\text { Allochthonous } \\
\text { arthropods }\end{array}$ & 4.7 & 3.1 & 3.5 & 0.7 & 3.4 & 3.0 & 1.1 & 3.1 & 2.1 & 0.2 & 0.3 & 0.3 & 0.4 & 0.1 & 0.2 & 4.6 & 20.1 & 18.3 & 3.7 \\
\hline $\begin{array}{l}\text { Fragment of } \\
\text { insects }\end{array}$ & 2.4 & 0.2 & 0.5 & 1.1 & 2.6 & 2.6 & 0.1 & 1.4 & 0.7 & 0.1 & 0.6 & 0.4 & 0.4 & 0.0 & 0.1 & 0.1 & 0.0 & 0.0 & 0.4 \\
\hline Aranae & - & - & - & - & 0.0 & 0.0 & - & - & - & - & 0.0 & 0.0 & - & - & - & - & - & - & 0.0 \\
\hline Orthoptera & - & - & - & - & - & - & - & - & - & - & - & - & - & 0.0 & 0.0 & - & - & - & 0.0 \\
\hline Coleoptera & 0.1 & 1.0 & 0.6 & 0.0 & - & 0.0 & - & - & - & - & - & - & - & - & - & 0.0 & 0.0 & 0.0 & 0.0 \\
\hline Heteroptera & - & - & - & - & 0.1 & 0.1 & 0.0 & - & 0.0 & 0.0 & - & 0.0 & - & - & - & - & 0.0 & 0.0 & 0.0 \\
\hline Hymenoptera & - & - & - & - & - & - & - & 0.1 & 0.0 & - & - & - & - & - & - & - & - & - & 0.0 \\
\hline Trichoptera & - & - & - & - & - & - & - & - & - & - & - & - & 0.0 & - & 0.0 & - & - & - & 0.0 \\
\hline Isoptera & 0.0 & 0.2 & 0.1 & - & - & - & 0.2 & 0.0 & 0.1 & - & - & - & - & - & - & 2.2 & 17.0 & 14.4 & 0.8 \\
\hline $\begin{array}{l}\text { Mammal } \\
\text { fragments }\end{array}$ & - & 0.1 & 0.0 & - & 0.0 & 0.0 & - & 3.0 & 1.0 & 1.9 & - & 0.1 & - & - & - & - & - & - & \\
\hline Hair & - & 0.1 & 0.0 & - & 0.0 & 0.0 & - & 0.2 & 0.1 & - & - & - & - & - & - & - & - & - & 0.0 \\
\hline $\begin{array}{l}\text { Mammal } \\
\text { fragments }\end{array}$ & - & - & - & - & - & - & - & 2.9 & 0.9 & 1.0 & - & 0.1 & - & - & - & - & - & - & 0.0 \\
\hline \multicolumn{20}{|l|}{$\begin{array}{l}\text { Animal } \\
\text { (autochthonous) }\end{array}$} \\
\hline $\begin{array}{l}\text { Autochthonous } \\
\text { insects }\end{array}$ & 14.3 & 0.5 & 2.6 & 0.2 & 0.3 & 0.3 & 0.4 & 1.0 & 0.8 & 1.5 & 0.9 & 1.0 & 18.2 & 2.8 & 5.4 & - & 0.1 & 0.1 & 1.8 \\
\hline $\begin{array}{l}\text { Fragment of } \\
\text { insects }\end{array}$ & - & - & - & - & 0.1 & - & 0.0 & 0.0 & 0.0 & 0.6 & - & 0.1 & - & 0.0 & 0.0 & - & - & - & 0.0 \\
\hline $\begin{array}{l}\text { Larvae of } \\
\text { insects }\end{array}$ & - & - & - & - & - & 0.0 & - & - & - & - & 0.0 & 0.0 & - & - & - & - & - & - & 0.0 \\
\hline $\begin{array}{l}\text { Ephemeroptera } \\
\text { (Nymph) }\end{array}$ & - & - & - & 0.5 & 0.0 & 0.0 & 0.0 & 0.2 & 0.1 & 0.0 & - & 0.0 & 0.1 & - & 0.0 & - & 0.0 & 0.0 & 0.0 \\
\hline Ephemeridae & 7.3 & 0.4 & 1.5 & - & - & - & - & 0.0 & 0.0 & - & 0.5 & 0.2 & 12.8 & 2.3 & 4.2 & - & 0.0 & 0.0 & 0.8 \\
\hline Oligoneuridae & - & - & - & - & - & - & - & - & - & - & 0.0 & 0.0 & - & 0.0 & 0.0 & - & - & - & 0.0 \\
\hline Diptera (Larvae) & - & - & - & - & - & - & - & - & - & 0.0 & - & 0.0 & - & - & - & - & - & - & 0.0 \\
\hline Chironomidae & - & - & - & - & - & - & - & - & - & 0.0 & 0.0 & 0.0 & 0.0 & 0.0 & 0.0 & - & 0.0 & 0.0 & 0.0 \\
\hline $\begin{array}{l}\text { Larvae of } \\
\text { Odonata }\end{array}$ & 0.8 & - & 0.1 & - & - & - & 0.1 & - & 0.0 & - & 0.0 & 0.0 & - & - & - & - & 0.0 & 0.0 & 0.0 \\
\hline Crustaceans & 8.2 & 3.6 & 4.9 & 0.5 & 1.7 & 1.6 & - & - & - & 0.0 & 0.0 & 0.0 & - & 0.0 & 0.0 & - & - & - & 0.2 \\
\hline $\begin{array}{l}\text { Crustacea } \\
\text { (Brachyura) }\end{array}$ & 0.3 & 0.8 & 0.7 & 0.4 & 0.3 & 0.4 & - & - & - & - & - & - & - & 0.0 & 0.0 & - & - & - & 0.0 \\
\hline $\begin{array}{l}\text { Crustacea } \\
\text { (Caridea) }\end{array}$ & 6.1 & 1.1 & 2.1 & 0.1 & 0.6 & 0.6 & - & - & - & - & 0.0 & 0.0 & - & - & - & - & - & - & 0.1 \\
\hline Fish fragments & 60.8 & 80.3 & 76.7 & 97.7 & 84.5 & 87.5 & 90.1 & 88.0 & 89.7 & 91.0 & 89.5 & 89.4 & 27.6 & 8.8 & 13.9 & 92.7 & 30.0 & 42.5 & 63.7 \\
\hline Fish fragments & 75.9 & 83.4 & 82.6 & 69.2 & 85.7 & 85.7 & 91.1 & 90.2 & 91.5 & 92.9 & 75.2 & 82.0 & 24.1 & 3.2 & 6.7 & 94.9 & 26.5 & 40.8 & 59.2 \\
\hline Characiformes & - & - & - & - & - & - & - & - & - & - & 4.9 & 2.1 & - & 0.6 & 0.3 & - & - & - & 0.2 \\
\hline Siluriformes & - & - & - & 25.7 & 0.1 & 1.1 & - & - & - & - & 0.4 & 0.2 & - & - & - & - & - & - & 0.0 \\
\hline Doradidae & - & - & - & - & - & - & - & - & - & - & - & - & - & - & - & - & 0.3 & 0.2 & 0.0 \\
\hline Symbranchidae & - & - & - & 0.6 & - & 0.0 & - & - & - & - & - & - & - & - & - & - & - & - & 0.0 \\
\hline
\end{tabular}


Table 1. continuation

\begin{tabular}{|c|c|c|c|c|c|c|c|c|c|c|c|c|c|c|c|c|c|c|c|}
\hline \multirow{3}{*}{ Food items } & \multicolumn{6}{|c|}{ Receding water } & \multirow{2}{*}{\multicolumn{3}{|c|}{$\begin{array}{c}\text { Drought } \\
\text { Nov./2010 }\end{array}$}} & \multirow{2}{*}{\multicolumn{3}{|c|}{$\begin{array}{c}\text { Rising water } \\
\text { Jan./2011 }\end{array}$}} & \multicolumn{6}{|c|}{ Flood } & \multirow{3}{*}{$\begin{array}{l}\text { IAi\% } \\
\text { Total }\end{array}$} \\
\hline & \multicolumn{3}{|c|}{ Jul./2010 } & \multicolumn{3}{|c|}{ Sep./2010 } & & & & & & & \multicolumn{3}{|c|}{ Mar./2011 } & \multicolumn{3}{|c|}{ May/2011 } & \\
\hline & Juv & Adu & Total & Juv & Adu & Total & Juv & Adu & Total & Juv & Adu & Total & Juv & Adu & Total & Juv & Adu & Total & \\
\hline Gymnotiformes & - & - & - & - & - & - & - & - & - & - & - & - & 0.4 & - & 0.0 & - & - & - & 0.0 \\
\hline \multicolumn{20}{|l|}{$\begin{array}{l}\text { Plantae } \\
\text { (Allochthonous) }\end{array}$} \\
\hline $\begin{array}{l}\text { Frag. of fruits } \\
\text { and seeds }\end{array}$ & 0.1 & 11.1 & 9.4 & 0.7 & 3.9 & 3.2 & 5.1 & 1.7 & 3.2 & 2.9 & 8.6 & 8.2 & 52.2 & 88.0 & 80.0 & 2.5 & 49.0 & 38.5 & 29.1 \\
\hline $\begin{array}{l}\text { Frag. of fruits } \\
\text { and seeds }\end{array}$ & 0.1 & 11.6 & 9.8 & 1.8 & 4.2 & 4.1 & 5.2 & 1.7 & 3.3 & 3.0 & 17.0 & 13.3 & 60.7 & 93.6 & 88.3 & 2.6 & 55.5 & 43.8 & 36.6 \\
\hline $\begin{array}{l}\text { Other } \\
\text { fragments of } \\
\text { plant }\end{array}$ & 1.0 & 0.8 & 0.9 & 0.0 & 3.2 & 2.3 & 0.3 & 2.8 & 1.5 & 2.0 & 0.7 & 0.9 & 0.7 & 0.2 & 0.3 & 0.2 & 0.6 & 0.5 & 0.9 \\
\hline $\begin{array}{l}\text { Other fragments } \\
\text { of plant }\end{array}$ & 1.2 & 0.9 & 0.9 & 0.1 & 3.4 & 2.9 & 0.3 & 2.9 & 1.5 & 2.0 & 1.2 & 1.4 & 0.8 & 0.2 & 0.3 & 0.2 & 0.6 & 0.6 & 1.1 \\
\hline \multicolumn{20}{|l|}{$\begin{array}{l}\text { Plantae } \\
\text { (Autochthonous) }\end{array}$} \\
\hline Algae & 0.3 & 0.1 & 0.1 & 0.1 & 2.1 & 1.6 & 2.8 & 0.3 & 1.6 & 0.2 & 0.1 & 0.1 & - & 0.0 & 0.0 & 0.0 & 0.1 & 0.1 & 0.3 \\
\hline Algae & 0.4 & 0.1 & 0.1 & 0.3 & 2.3 & 2.0 & 2.9 & 0.3 & 1.7 & 0.2 & 0.1 & 0.1 & - & 0.0 & 0.0 & 0.0 & 0.1 & 0.1 & 0.4 \\
\hline \multicolumn{20}{|l|}{ Origin unknown } \\
\hline $\begin{array}{l}\text { Arthropod } \\
\text { fragments }\end{array}$ & 10.6 & 0.3 & 1.8 & - & 1.0 & 0.6 & 0.0 & 0.1 & 0.0 & 0.1 & 0.0 & 0.0 & 0.4 & 0.0 & 0.1 & - & - & - & 0.2 \\
\hline $\begin{array}{l}\text { Fragment } \\
\text { exoskeleton }\end{array}$ & 1.8 & - & 0.1 & - & 0.0 & 0.0 & - & 0.0 & 0.0 & 0.0 & 0.0 & 0.0 & 0.0 & 0.0 & 0.0 & - & - & - & 0.0 \\
\hline $\begin{array}{l}\text { Fragment of } \\
\text { insects }\end{array}$ & 3.7 & 0.3 & 0.9 & - & 0.6 & 0.5 & 0.0 & 0.0 & 0.0 & 0.0 & 0.0 & 0.0 & 0.1 & 0.0 & 0.0 & - & - & - & 0.1 \\
\hline $\begin{array}{l}\text { Inorganic } \\
\text { material }\end{array}$ & - & - & - & - & 0.0 & 0.0 & - & - & - & 0.1 & - & 0.0 & 0.5 & 0.0 & 0.1 & 0.0 & 0.0 & 0.0 & 0.0 \\
\hline $\begin{array}{l}\text { Inorganic } \\
\text { material }\end{array}$ & - & - & - & - & 0.0 & 0.0 & - & - & - & 0.1 & - & 0.0 & 0.5 & 0.0 & 0.1 & 0.0 & - & 0.1 & 0.0 \\
\hline
\end{tabular}

the diet showed an average similarity of $64.65 \%$ where fish fragments accounted for $44.87 \%$ of the species diet followed by fragments of fruits and seeds (39.92\%) and arthropod fragments (7.55\%) (Figure 2 B-D).

In terms of feeding intensity, an increase in the repletion index was recorded during the rise in the water level (Figure 3). Among juveniles, this variation was less evident $\left(\mathrm{H}_{(5,98)}=15.18, \mathrm{p}=0.009\right)$ (Figure $3 \mathrm{~A}$ ) with the feeding intensity observed during the flood season (RI\% = $0.50 \pm 0.61$, Mean $\pm S D$ ) differing only from the rising water season $(\mathrm{RI} \%=0.08 \pm 0.46)\left(z^{\prime}=3.14, p=0.025\right)$. In adults specimens, a remarkable feeding intensity was observed $(\mathrm{H}$ ${ }_{(5.162)}=25.60 \mathrm{p}<0.001$ ) (Figure 3B), with a low feeding intensity recorded at the end of the drought season (RI\% $=0.13 \pm 0.16$ ), while an increasement was observed at the beginning of flood season (March, RI\% $=0.89 \pm 0.88$ ). This increase in feeding activity was significantly different of all other hydrological periods as suggested by a posteriori test (March/July: $\mathrm{z}^{\prime}=3.61, \mathrm{p}=0.004 ; \mathrm{March} /$ September: $\mathrm{z}^{\prime}=3.42, \mathrm{p}=0.009 ;$ March/November: $\mathrm{z}^{\prime}=4.10, \mathrm{p}<0.001$; March/January: $\mathrm{z}^{\prime}=3.05, \mathrm{p}=0.003$ ).
In the present study, S. gouldingi showed high feeding specificity, indicated by lower values of niche breadth $\left(\mathrm{B}_{\mathrm{a}}<0.07\right)$ (Figure 4), that in turn, varied between different hydrological periods. Adults showed higher feeding specificity during early flood season $\left(B_{a}=0.01\right)$, predominantly consuming fruits and seeds $\left(\mathrm{AI}_{\mathrm{i}} \%=\right.$ 87.98\%). A slightly more generalist diet was observed both during the late flood season $\left(B_{a}=0.06\right)$ and rising water season $\left(B_{a}=0.07\right)$, where it was mainly composed by fruits and seeds ( $\mathrm{AI}_{\mathrm{i}} \%=49.04 \%$ in May and $8.58 \%$ in January), fish fragments $\left(\mathrm{AI}_{\mathrm{i}} \%=89.71 \%\right.$ in May and $30.05 \%$ in January) and allochthonous arthropods $\left(\mathrm{AI}_{\mathrm{i}} \%=20.13 \%\right.$ in May and only $0.07 \%$ in January).

On the other hand, juveniles specimens showed lower niche breadth during drought and early rising water season (both with $\mathrm{B}_{\mathrm{a}}=0.03$ ), with predominance of fish fragments $\left(\mathrm{AI}_{\mathrm{i}} \%=90.11 \%\right.$ in November and $90.99 \%$ in January $)$ (Figure 4, Table 1). During receding water season, the diet was slightly more generalist $\left(B_{a}=0.06\right)$, with an increase in consumption of autochthonous insects $\left(\mathrm{AI}_{\mathrm{i}} \%=14.26 \%\right.$ ) 

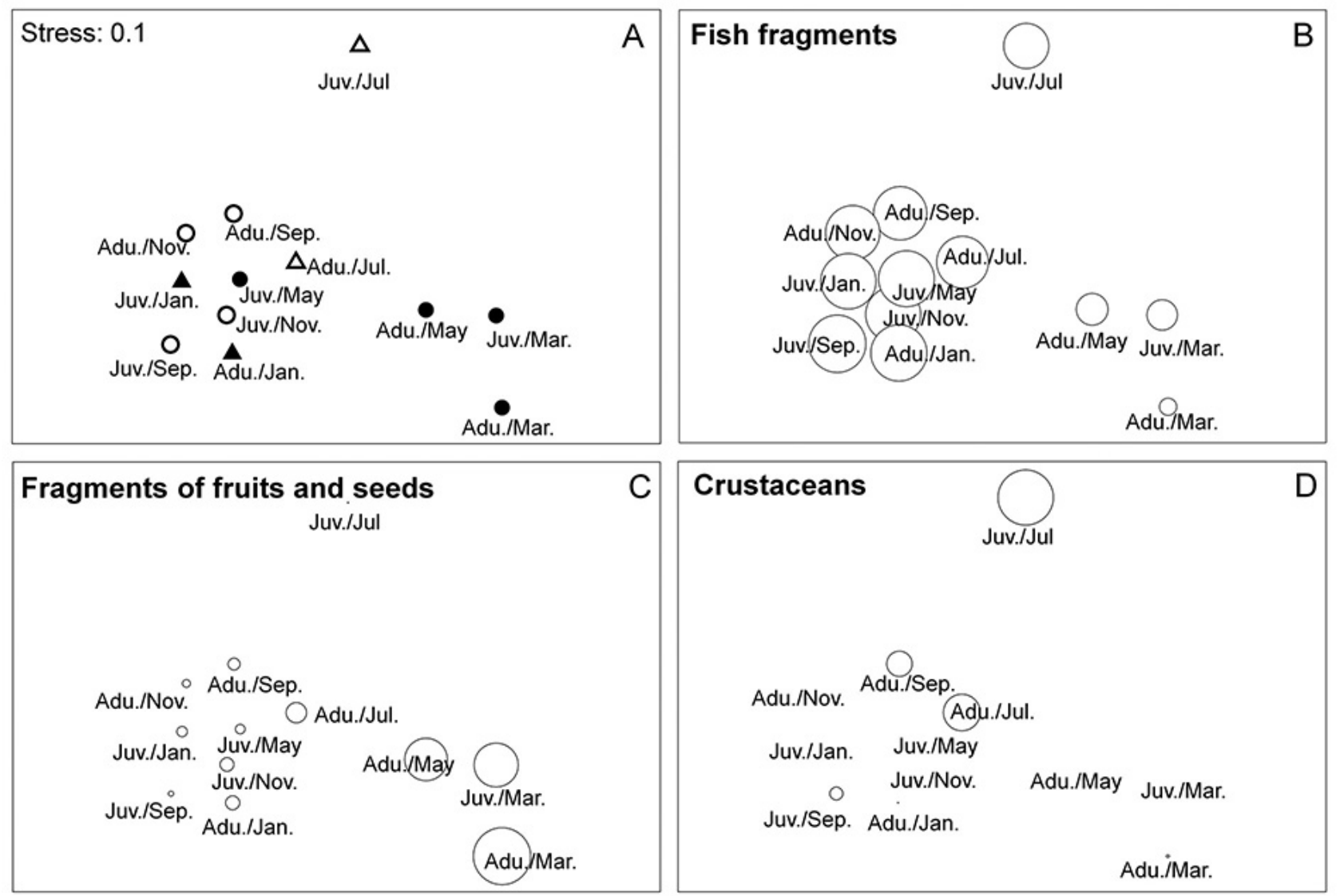

Figure 2. Graphic representation of the non-metric multidimensional scaling analysis (nMDS) of diet of Serrasalmus gouldingi in the lower Anapu River region between July, 2010, and May, 2011. Where open circles ( $($ ) represent the drought season, open triangles $(\Delta)$, the receding water season, closed triangles $(\boldsymbol{\Delta})$ the rising water season and closed circles $(\bullet)$ the flood season $(A)$. The contribution of each dietary category is proportional to the circle size for fish fragments (B), fragments of fruits and seeds (C), and crustaceans (D).
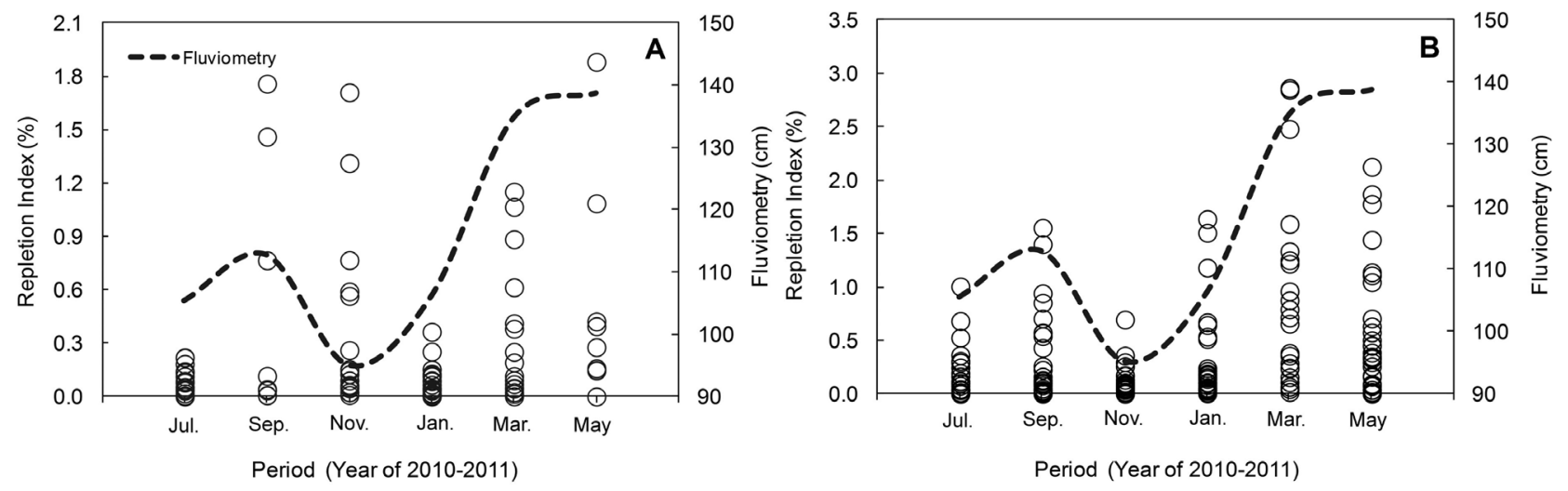

Figure 3. Variation in the Repletion Index (Rl\%) of juveniles (A) and adults (B) of Serrasalmus gouldingi in lower Anapu River region between July, 2010, and May, 2011. 


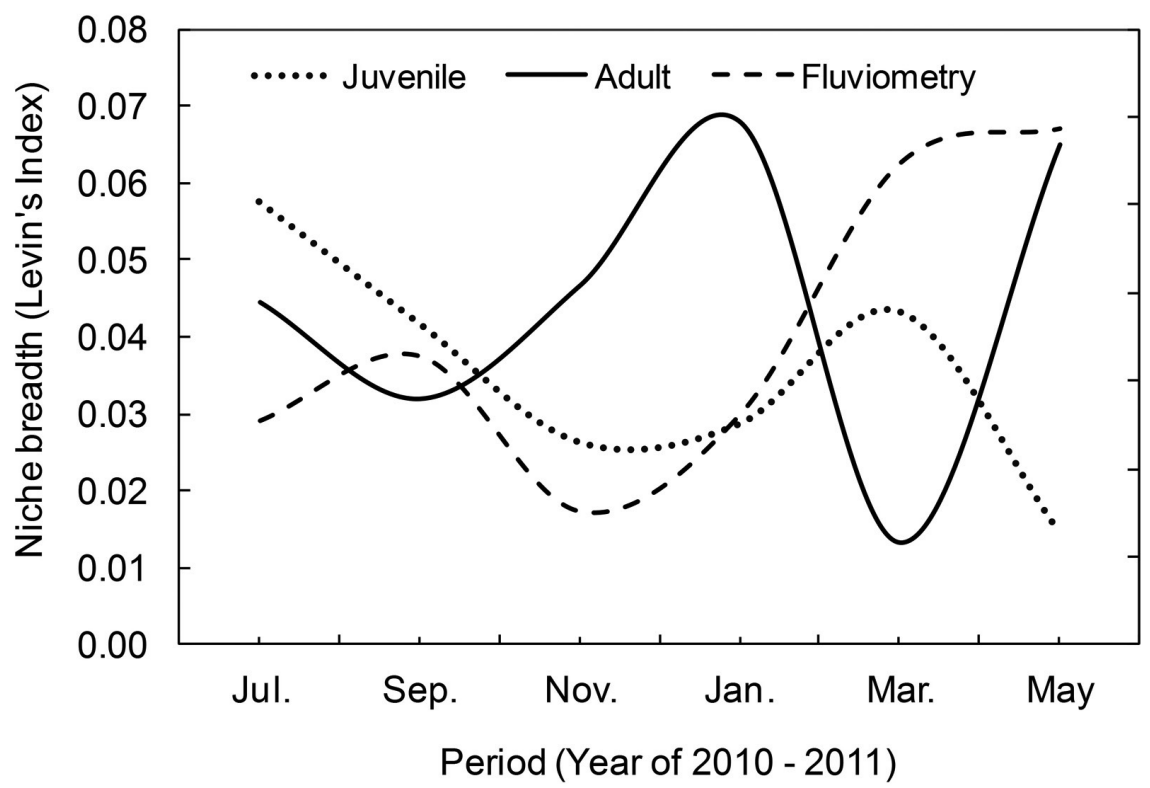

Figure 4. Trophic niche breadth of juveniles and adults of Serrasalmus gouldingi in the lower Anapu River region in relation to the different hydrological periods between July, 2010, and May, 2011.

and arthropods fragments $\left(\mathrm{AI}_{\mathrm{i}} \%=10.56 \%\right)$ and a decrease in consumption of fish fragments $\left(\mathrm{AI}_{\mathrm{i}} \%=60.83 \%\right)$.

\section{DISCUSSION}

Fish fragments were the most frequent category found in the stomach content of S. gouldingi throughout the study period. Fruits and seeds were the second more frequent category, being remarkably important during flood season. Thereby, populations of S. gouldingi may be characterized as omnivorous, with a strong tendency towards piscivory. This corroborates other studies involving piranhas from the same genus in different watersheds (Leão et al. 1991; Agostinho et al. 2003; Piorski et al. 2005). As observed in S. gouldingi, high consumption of Characiformes fishes has been recorded for other piscivorous fish species of tropical regions, and is probably related to the high specific diversity of the group (Bozza and Hahn 2010; Santos et al. 2014), which is also abundant in the lower Anapu River (Montag et al. 2009b).

The presence of plant materials in the diet of $S$. gouldingi corroborates studies involving other species of the genus, where the presence of this item was considered as an accidental ingestion due to the animal's foraging habit, seeking for prey in marginal vegetation or in areas with higher concentrations of aquatic macrophytes (Nico and Taphorn 1988; Carvalho et al. 2007; Ferreira et al. 2014). On the other hand, the consumption of such items may represent an energy-maximizing strategy, given these resources are especially abundant in some periods of the year, facilitating their consumption (Correa et al. 2007; Barbosa et al. 2015). Fruits and seeds contain large fractions of carbohydrates and are rich in fats and proteins, providing an important resource for the reproductive process of some fish species (Goulding 1980; Correa et al. 2007).

From an evolutionary perspective, a frugivorous diet has been thought as a characteristic derived from an originally omnivorous diet, that became more specialized due to nutritional advantages of a seasonally abundant resource (Correa et al. 2007). Phylogenetic interactions based on the presence or absence of plant materials in the diet of serrasalmids are consistent with morphological variations, such as dentition and buccal apparatus, associated to dietary specializations (Correa et al. 2007). However, such proposition still considers species of the genus Serrasalmus as exclusively piscivorous, contradicting our results.

Whereas the diet of fishes represents the interaction between preferences, availability and accessibility of items in the environment (Correa and Winemiller 2014; Mortillaro et al. 2015), this study considers that fruits and seeds ingestion by $S$. gouldingi is not accidental, but rather a response to increased availability of this resource during flood season. During this season, a large amount of fruits produced by floodplain trees fall into the water and are ingested or dispersed by many different fish species (Claro-Jr et al. 2004; Ferreira and Parolin 2007; Freitas et al. 2011). Therefore, our results are consistent with the results of other studies carried out in Amazonia involving 
Serrasalmus, in the upper Madeira River (Goulding 1980) and in the lower Negro River (Leâo et al. 1991), where a higher amount of fruits and seeds was consumed during flood season. However, the importance of fruits and seeds in $S$. gouldingi diet may be better understood using stable isotopes, which might confirm how much of the available energy in fruits and seeds has been assimilated by the species (Post 2002; Mortillaro et al. 2015).

Differences in diet composition of S. gouldingi, between hydrological periods, combined with the increase in feeding activity during flood season, indicate that hydrologic variation is an important determining factor in qualitative and quantitative characteristics of the feeding ecology of this species. This was also demonstrated by studies on many tropical fishes living in habitats influenced by flood pulses (Winemiller 2005; Freitas et al. 2011; Correa and Winemiller 2014). During high water season, the flooding of adjacent areas not only contributes to nutrients input into the aquatic ecosystem (such as terrestrial invertebrates, fruits and seeds), but also allows for the exploitation of available resources in these areas (Junk et al. 1989; Winemiller 2005).

Juveniles and adults of $S$. gouldingi presented similar diet composition, rejecting the previous hypothesis that physiological and morphological differences resulting from life stages, could affect the feeding ecology of fishes (Scarnecchia et al. 2007; Ballesteros et al. 2009). Although ontogenetic variations have been evidenced in the diet of Serrasalmus species (Machado-Allison and Garcia 1986; Almeida et al. 1998), they have been closely related to the morphological limitations found in smaller individuals, preventing them to use the same resources consumed by adults (Machado-Allison and Garcia 1986). According to Almeida et al. (1998), predatory activities of $S$. marginatus start in individuals with four $\mathrm{cm}$ standard length. However, the present study did not record individuals measuring less than nine centimeters of total length, which precluded the assessment of the effects of morphological variation on diet composition of $S$. gouldingi.

Differences in feeding intensity between hydrological periods reinforce the hypothesis that part of the variation observed in fish diet is related to seasonality of resource availability, since increased river level provides an increment of resources in flood plains, which are frequently used by the species (Junk et al. 1989; Correa and Winemiller 2014; Mortillaro et al. 2015).

Niche breadth is an important complementary parameter for the analysis of fish diets, especially because it provides insights about variations in the specificity of the diet over a given period. The reduced niche breadth here observed, is similar to a number of previous studies on predominantly piscivorous fishes, such as those from the floodplains of the upper Paraná River, in Brazil (Bozza and Hahn 2010).

In many piscivorous fishes, the presence of a specialized diet may be related to morphological adaptations that favor the consumption of a certain item, prey availability in the environment or even to the marked abundance of a given resource during a specific period (Crowder and Cooper 1982; Novakowski et al. 2008). In this study, the reduction of niche breadth in adult specimens during flood season, with an increase in niche breadth of juveniles over the same season, suggests a possible change in habitat use throughout the development of species. Several behavioral characteristics of piranhas of the genus Serrasalmus, such as seasonal migration patterns (Sazima and Machado 1990; Winemiller and Jepsen, 1998) and the use of floodplain vegetation for nest construction during spawning period (Géry 1977; Honorato-Sampaio et al. 2009), may contribute to this variation in habitat use.

Studies on niche breadth of piscivorous fish species have found widely divergent patterns. Some studies have evidence a more generalist diet during flood season (LuzAgostinho et al. 2008; Corrêa et al. 2011), while others observed specialized diets during the same season (SáOliveira et al. 2014). Our results reinforce the hypothesis that there is no universal pattern in the exploitation of resources, but rather a variety of behavioral strategies related to the environmental characteristics of each system (Novakowski et al. 2008).

\section{CONCLUSION}

Our results indicate that the $S$. gouldingi population in the lower Anapu river region can be characterized as omnivorous with a strong tendency towards piscivory. Changes in feeding ecology of the species were not related with individuals' life stage, once juveniles and adults showed similar diet composition and feeding intensity. In addition, flood pulse is still an important factor influencing the feeding ecology of this piranha species, although it is less evident than in most watersheds of the Amazon region. This influence should be taken into account in future conservation and management plans concerning aquatic ecosystems of this region and its fish communities.

\section{ACKNOWLEDGMENTS}

We are grateful to Ferreira Penna Scientific Station (ECFP) for logistic support and the Biodiversity Research Program (PPBio) for the financial support during the fieldwork. We also thank the Coordination of Superior Level Staff Improvement (CAPES) for granting a 
scholarship and to the National Council of Technological and Scientific Development (CNPq) for the productivity grants provided to LFAM (process: 301343/2012-8).

\section{REFERENCES}

Agostinho, C.S.; Hahn, N.S; Marques, E.E. 2003. Patterns of food resource use by two congeneric species of piranhas (Serrasalmus) on the upper Paraná River floodplain. Brazilian Journal of Biology, 63: 177-182.

Almeida, V.L.L.; Hahn, N.S.; Agostinho, C.S. 1998. Stomach content of juvenile and adult piranhas (Serrasalmus marginatus) in the Paraná floodplains, Brazil. Studies on Neotropical Fauna and Environment, 33: 37-41.

Anderson, M.J. 2001. A new method for non-parametric multivariate analysis of variance. Austral Ecology, 26: 32-46.

Anderson,, M.J.; Gorley, R.N.; Clarke, K.R. 2008. PERMANOVA+ for PRIMER: Guide to Software and Statistical Methods. PRIMER-E, Plymouth, UK, 199p.

Ballesteros, T.M.; Torres-Mejia, M.; Ramírez-Pinilla, M.P. 2009. How does diet influence the reproductive seasonality of tropical freshwater fish? A case study of a characin in a tropical mountain river. Neotropical ichthyology, 7: 693-700.

Barbosa, T.A.P.; Barthem, R.B.; Montag, L.F.A. 2015. Feeding ecology of immature Lithodoras dorsalis (Valenciennes, 1840) (Siluriformes: Doradidae) in a tidal environment, estuary of the rio Amazonas. Neotropical Ichthyology, 13: 341-348.

Behling, H.; Costa, M.L. 2000. Holocene Environmental Changes from the Rio Curua Record in the Caxiuanã Region, Eastern Amazon Basin. Quaternary Research, 53: 369-377.

Behr, E.R.; Signor, C.A. 2008. Distribuição e alimentação de duas espécies simpátricas de piranhas Serrasalmus maculatus e Pygocentrus nattereri (Characidae, Serrasalminae) do Rio Ibicuí, Rio Grande do Sul, Brasil. Iheringia. Série Zoologia, 98: 501-507.

Bozza, A.N.; Hahn, N.S. 2010. Uso de recursos alimentares por peixes imaturos e adultos de espécies piscívoras em uma planície de inundação neotropical. Biota Neotropica, 10: 217-223.

Braga, R.R.; Bornatowski, H.; Vitule, J.R.S. 2012. Feeding ecology of fishes: an overview of worldwide publications. Reviews in Fish Biology and Fisheries, 22: 915-929.

Carvalho, L.N.; Arruda, R.; Raizer, J.; Del-Claro, K. 2007. Feeding habits and habitat use of three sympatric piranha species in the Pantanal Wetland of Brazil. Ichthyological Exploration of Freshwaters, 18: 109-116.

Clarke, K.R.; Gorley, R.N. 2006. Software PRIMER v5. Plymouth, PRIMER-E, UK.

Clarke, K.R.; Warwick, R.M. 2001. Change in marine communities: an approach to statistical analysis and interpretation. Plymouth, Plymouth Marine Laboratory, 859p.

Claro-Jr, L.; Ferreira, E.; Zuanon, J.; Araujo-Lima, C. 2004. O efeito da floresta alagada na alimentaçáo de três espécies de peixes onívoros em lagos de várzea da Amazônia Central, Brasil. Acta Amazonica, 34: 133-137.
Corrêa, C.E.; Albrecht, M.P.; Hahn, N.S. 2011. Patterns of niche breadth and feeding overlap of the fish fauna in the seasonal Brazilian Pantanal, Cuiabá River basin. Neotropical Ichthyology, 9: 637-646.

Correa, S.B.; Winemiller, K.O. 2014. Niche partitioning among frugivorous fishes in response to fluctuating resources in the Amazonian floodplain forest. Ecology, 95: 210-224.

Correa, S.B.; Winemiller, K.O.; López-Fernández, H.; Galetti, M. 2007. Evolutionary Perspectives on Seed Consumption and Dispersal by Fishes. Bioscience Journal, 57:748-756.

Costa, C.; Ide, S.; Simonka, C.E. 2006. Insetos Imaturos: Metamorfose e Identificação. Holos, Ribeirão Preto, 249p.

Crowder, L.B.; Cooper, W.E. 1982. Habitat structural complexity and the interaction between bluegills and their prey. Ecology, 63: 1802-1813.

Ferreira, F.S.; Vicentin, W.; Costa, F.E.S.; Súarez, Y.R. 2014. Trophic ecology of two piranha species, Pygocentrus nattereri and Serrasalmus marginatus (Characiformes, Characidae), in the floodplain of the Negro River, Pantanal. Acta Limnologica Brasiliensia, 26: 381-391.

Ferreira, L.V.; Parolin, P. 2007. Tree phenology in Central Amazonian Floodplain forests: effects of water level fluctuation and precipitation at community and population level. Pesquisas série Botânica, 58: 139-156.

Fink, W.L.; Machado-Allison, A. 1992. Three new species of piranha from Brazil e Venezuela (Teleostei: Characiformes). Ichthyological Exploration of Freshwaters, 3: 55-71.

Freitas, T.M.S.F.; Almeida, V.H.C.; Valente, R.M.; Montag, L.F.A. 2011. Feeding ecology of Auchenipterichthys longimanus (Siluriformes: Auchenipteridae) in a riparian flooded forest of Eastern Amazonia, Brazil. Neotropical Ichthyology, 9: 629-636.

Géry, J. 1977. Characoids of the world. T.F.H. Publ., Neptune, U.S.A, 672 p.

Goulding, M. 1980. The fishes and Forest: explorations in Amazon natural history. Berkeley: University of California Press, U.S.A., 280p.

Hida, N.; Maia, J.G.; Hiraoka, M.; Shimm, O.; Nobuaki, M. 1999. River water level changes of the Amazon Estuary: at Breves, Caxiuaná and Abaetetuba. Manaus'99 - Hydrological and geochemical processess in large scale river basins, 1-9.

Honorato-Sampaio, K.; Santos, G.B.; Bazzoli, N; Rizzo, E. 2009. Observation of seasonal breeding biology and fine structure of the egg surface in the white piranha Serrasalmus branditti from the São Francisco River basin, Brazil. Journal of Fish Biology, 75:1874-1882.

Horn, M.H.; Correa, S.B.; Parolin, P.; Pollux, B.J.A.; Anderson, J.T.; Lucas C.; Widmann, P.; Tjiu, A.; Galetti, M.; Goulding, M. 2011. Seed dispersal by fishes in tropical and temperate fresh waters: The growing evidence. Acta Oecologica, 37: 561-577.

Hurlbert, S.H. 1978. The measurement of niche overlap and some relatives. Ecology, 59: 67-77.

Hynes, H.B.N. 1950. The food of fresh water Sticklebacks (Gasterosteus aculeatus and Pygosteus pungitius), with a review 
of methods used in studies of the fishes. Journal of Animal Ecology, 19: 36-58.

Hyslop, E.J. 1980. Stomach contents analysis: a review of methods and their application. Journal of Fish Biology, 17: 411-429.

Junk, W.J.; Bayley, P.B.; Sparks, R.E. 1989. The flood pulse concept in river-floodplain systems. Canadian Journal of Fisheries and Aquatic Sciences, 106: 110-127.

Junk, W.J.; Furch, K. 1993. A general review of tropical South American floodplains. Wetlands Ecology and Management, 2: $231-238$.

Kawakami, E.; Vazzoler, G. 1980. Método gráfico e estimativa de índice alimentar aplicado no estudo de alimentação de peixes. Boletim do Instituto Oceanográfico, 29: 205-207.

Leão, E.L.M.; Leite, R.G.; Chaves, P.T.C.; Ferraz, E. 1991. Aspectos da reproduçáo, alimentaçáo e parasitofauna de uma espécie rara de piranha Serrasalmus altuvei, Ramíres, 1965 (Pisces: Serrasalmidae) do baixo Rio Negro. Revista Brasileira de Biologia, 51: 545-553.

Luz-Agostinho, K.D.G.; Agostinho, A.A.; Gomes, L.C.; Júlio Jr., H.F. 2008. Influence of flood pulses on diet composition and trophic relationships among piscivorous fish in the upper Parana River floodplain. Hydrobiologia, 607:187-198.

Machado-Allison, A.; Garcia, C. 1986. Food habits and morphological changes during ontogeny in three Serrasalmin species of Venezuelan flood plain. Copeia, 1:93-96.

Montag, L.F.A.; Freitas, T.M.S.; Castro, N.C.; Wosiacki, W.B.; Barthem, R.B. 2009b. Ictiofauna: diversidade e conservação. In: Lisboa, P.L.B. (Ed.). Caxiuanã: Desafio para a conservação em uma Floresta Nacional na Amazônia. Belém, Museu Paraense Emílio Goeldi, p. 605-628.

Montag, L.F.A.; Wosiacki, W.B.; Barthem, R.B. 2009a. A ecologia da pesca na Floresta Nacional de Caxiuanã. In: Lisboa, P.L.B. (Ed.). Caxiuanã: Desafio para a conservação em uma Floresta Nacional na Amazônia. Belém, Museu Paraense Emílio Goeldi, p. 629-648.

Moraes, B.C.; Silva, R.M.; Ribeiro, J.B.M.; Ruivo, M.L.P. 2009. Variabilidade de precipitação na floresta de Caxiuanã. In: Lisboa PLB (Org.). Caxiuaná: Desafio para a conservação em uma Floresta Nacional na Amazônia. Belém, Museu Paraense Emílio Goeldi. p. 91-98.

Mortillaro, J.M.; Pouilly, M.; Wach, M.; Freitas, C.E.C.; Abril, G.; Meziane, T. 2015. Trophic opportunism of central Amazon floodplain fish. Freshwater Biology, 60, 1659 - 1670.

Nico, L.G.; Taphorn, D.C. 1988. Food habits of piranha in the low Llanos of Venezuela. Biotropica, 20: 311-321.

Novakowski, G.C.; Hahn, N.S.; Fugi, R. 2008. Diet seasonality and food overlap of the fish assemblage in a Pantanal pond. Neotropical Ichthyology, 6: 567-576.
Piorski, N.M.; Alves, J.R.L.; Machado, M.R.B.; Correia, M.M.F. 2005. Alimentação e ecomorfologia de duas espécies de piranhas (Characiformes: Characidae) do lago de Viana, estado do Maranhão, Brasil. Acta Amazônica, 35: 63-70.

Post, D.M. 2002. Using stable isotopes to estimate trophic position: models, methods, and assumptions. Ecology, 83: 703-718.

Prudente, B.P; Ferreira, M.A.P.; Rocha, R.M.; Montag, L.F.A. 2015. Reproductive biology of the piranha Serrasalmus gouldingi (Fink and Machado-Allison 1992) (Characiformes: Serrasalmidae) in "drowned" rivers of the Eastern Amazon. Environmental Biology of Fishes, 98: 11-22.

Santos, N.C.L dos; Medeiros, T. N.; Alves, A.; Rocha, F da; Dias, R. M.; Severi, W. 2014. Uso de recursos alimentares por Plagioscion squamosissimus-piscívoro não-nativo no reservatório de Sobradinho - BA, Brasil. Boletim do Instituto de Pesca, 40: 397-408

Sá-Oliveira, J.C.; Angelini, R.; Isaac-Nahum, V.J. 2014. Diet and niche breadth and overlap in fish communities within the area affected by an Amazonian reservoir (Amapá, Brazil). Anais da Academia Brasileira de Ciências, 86: 383-405.

Sazima, I.; Machado, F.A. 1990. Underwater observations of piranhas in western Brazil. Environmental Biology of Fishes, 28:17-31.

Scarnecchia, D.L.; Ryckman, L.F.; Lim, Y.; Power, G.J.; Schmitz, B.J.; Firehammer, J.A. 2007. Life history and the costs of reproduction in Northern Great Plains Paddlefish (Polyodon spathula) as a potential framework for other Acipenseriform fishes. Reviews in Fisheries Science, 15: 211-263.

Statsoft, Inc. 2007. Statistica (data analysis software system). Version 8.0.

Trindade, M.E.J.; Jucá-Chagas, R. 2008. Diet of two serrasalmin species, Pygocentrus piraya and Serrasalmus brandtii (Teleostei: Characidae), along a stretch of the Rio de Contas, Bahia, Brazil. Neotropical Ichthyology, 6: 645-650.

Winemiller, K. O. 2005. Floodplain river food webs: generalization and implications for fisheries management. In: Welcomme, R. L.; Petr, T. (Eds.). Proceeding of the second international symposium on the management of large rivers for fisheries. v. 2. Mekong River Commission, Phnom Penh, Camboya, p. 285-312.

Winemiller, K.O.; Jepsen, D.B. 1998. Efects of seasonality and fish movement on tropical river food webs. Journal of Fish Biology, 53: 267-296.

Zar, J.H. 1999. Biostatistical analysis. 4th ed. New Jersey, PrenticeHall, 663p.

Zavala-Camin, L.A. 1996. Introdução aos estudos sobre alimentação natural de peixes. EDUEM, Maringá, 129p.

Recebido em 17/01/2016

Aceito em 18/03/2016 
